\title{
Analisis Pengaruh Economic Value Added (EVA), Debt to Equity Ratio (DER), Return On Asset (ROA), dan Current Ratio (CR) terhadap Return Saham (Studi pada Perusahaan Sektor Pertambangan yang Terdaftar di Bursa Efek Indonesia Periode 2013-2017)
}

\author{
${ }^{1}$ Ni Made Diah Kartika Sari, ${ }^{2 *}$ Muhammad Rois, ${ }^{3}$ Pandiya \\ ${ }^{1}$ Alumni Jurusan Akuntansi, Politeknik Negeri Semarang \\ ${ }^{2,3}$ Jurusan Akuntansi Polines, Politeknik Negeri Semarang \\ *rhoeast@gmail.com
}

\begin{abstract}
This study aims to examine the significance of the effects of Economic Value Added, Debt to Equity Ratio, Return on Assets, and Current Ratio againts stock return in mining sector companies listed in Indonesia Stock Exchange 20132017. This study uses secondary data. The samples in this research are determined by purposive sampling technique. The samples used in this research are 6 (six) mining companies listed on Indonesia Stock Exchange. Testing hypothesis by using regression tool of panel data supported by software eviews 9. Results of $F$ test of this research show that Economic Value Added (EVA), Debt to Equity Ratio (DER), Return on Asset (ROA), simultaneously have a significant effect against stock returns on the company. The result of t test shows that the Economic Value Added partially does not have a significant effect on stock return, while the Debt to Equity Ratio, Return on Asset, and Current Ratio have significant effect to stock return on mining companies listed in Indonesia Stock Exchange period 2013-2017.
\end{abstract}

Keywords: Economic Value Added, Debt to Equity Ratio, Return on Asset, Current Ratio and Stock Return

\begin{abstract}
Abstrak
Penelitian ini bertujuan untuk menguji signifikansi pengaruh Economic Value Added, Debt to Equity Ratio, Return on Asset, dan Current Ratio terhadap return saham pada perusahaan sektor pertambangan yang terdaftar di Bursa Efek Indonesia tahun 2013-2017. Penelitian ini menggunakan data sekunder. Sampel dalam penelitian ini ditentukan dengan teknik purposive sampling. Sampel yang digunakan dalam penelitian ini adalah 6 (enam) perusahaan pertambangan yang terdaftar di Bursa Efek Indonesia. Pengujian hipotesis dengan menggunakan alat analisis regresi data panel dengan bantuan software eviews 9. Hasil F test dari penelitian ini menunjukan, bahwa Economic Value Added (EVA), Debt to Equity Ratio (DER), Return on Asset (ROA), secara simultan berpengaruh signifikan terhadap return saham pada perusahaan. Hasiluji t menunjukan, bahwa Economic Value Added secara parsial tidak berpengaruh signifikan terhadap return saham, sedangkan Debt to Equity Ratio, Return on Asset, dan Current Ratio berpengaruh signifikan terhadap return saham pada perusahaan sektor pertambangan yang terdaftar di Bursa Efek Indonesia periode 2013-2017.
\end{abstract}

Kata kunci : $\quad$ Economic Value Added, Debt to Equity Ratio, Return on Asset,Current Ratio dan Return saham

\section{Pendahuluan}

Pada era sekarang ini, pasar modal menjadi salah satu tempat alternatif pilihan bagi para investor dalam melakukan aktivitas investasi. Investasi saham biasanya disukai oleh para investor. Saham merupakan surat berharga yang menunjukkan bagian kepemilikan atas suatu perusahaan. Menurut Salim (2012:5), ketika investor memiliki saham sebuah perusahaan, bisa dikatakan investor memiliki perusahaan tersebut sebesar persentase tertentu, sesuai dengan jumlah lembar saham yang dimiliki. Tujuan investor berinvestasi di pasar modal adalah untuk mendapatkan return. Return saham adalah tingkat keuntungan atau laba yang diperoleh oleh investor dari investasi pada sahamnya, berdasarkan selisih perubahan harga saham periode sekarang dengan periode sebelumnya, kemudian dibagi dengan harga saham periode sebelumnya.

Sektor pertambangan merupakan sektor yang berkaitan dengan pengelolaan sumber daya mineral yang ada di dalam tanah, baik berbentuk cair (minyak) dan padat (batu bara, emas, nikel).

Alasan dalam penelitian ini menggunakan sektor pertambangan karena diketahui beberapa perusahaan di sektor ini memiliki return saham dibawah rata-rata return saham pada industri sektor pertambangan. Hal ini 
tentunya akan memberikan efek buruk bagi perusahaan dan juga para investor serta perekonomian di Indonesia.

Perkembangan return saham perusahaan sektor pertambangan tahun 2013 sampai tahun 2017 mengalami fluktuasi, namun pada tahun 2016 sempat meningkat cukup tinggi. Naiknya return tersebut bersamaan dengan naiknya IHSG di Indonesia pada tahun 2017 yang cukup tinggi dan dinyatakan baik. Namun, indeks sektoral pertambangan mengalami penurunan yang sangat dratis bahkan hingga memerah. Pada tahun 2017 ini perusahaan pertambangan mengalami penurunan paling buruk dari sektor lainnya. Selain itu, dilihat dari sisi perekonomian Indonesia, pada tahun 2017 perkembangan perekonomian Indonesia cukup membaik daripada tahun sebelumnya. Namun, tidak dengan sektor pertambangan yang semakin menurun .Halini tentunya akan memberikan efek buruk bagi perusahaan dan juga para investor, karena para investor tidak akan mendapatkan keuntungan yang mereka harapkan.Karena investor mengharapkan keuntungan yang besar, maka jika para investor tidak mendapatkan keuntungan yang mereka harapkan, mereka tidak akan memberikan dananya kepada perusahaan,yangberakibat, perusahaan akan kesulitan menjalankan usahanya tanpa modal dari investor.

Salah satu komponen yang harus diperhatikan yang berhubungan dengan return saham adalah EVA Economic Value Added.Economic Value Added (EVA) adalah ukuran keberhasilan manajemen perusahaan dalam meningkatkan nilai tambah (value added) bagi perusahaan. Asumsinya, jika kinerja manajemen baik atau efektif (dilihat dari besarnya nilai tambah yang diberikan), maka akan tercermin pada peningkatan harga saham perusahaan (Tandelilin, 2001:195). Menggunakan analisis EVA maka akan berdampak lebih baik terhadap return saham karena EVA merupakan laba yang tersisa, untuk itu semakin tinggi nilai EVA, maka akan dapat mempengaruhi return yang diterima oleh investor.

Selain itu, DER juga mempunyai peran yang penting dalam pengoperasian perusahaan. Penggunaan DER sebaiknya berdasarkan pada tingkat kebutuhan selama jangka waktu operasi perusahaan. Semakin panjang usia operasi perusahaan akan semakin tinggi DER yang dibutuhkan. Meskipun demikian, DER yang terlalu tinggi mempunyai dampak buruk terhadap kinerja perusahaan, karena tingkat utang yang semakin tinggi menandakan beban bunga perusahaan akan semakin besar dan mengurangi keuntungan, sehingga adakecenderungan menurunkan return saham.

Selanjutnya, salah satu hal yang dapat dipertimbangkan investor adalah return perusahaan. Return on Assets (ROA) adalah rasio keuangan perusahaan yang terkait dengan potensi keuntungan mengukur kekuatan perusahaan membuahkan keuntungan atau juga laba pada tingkat pendapatan, aset dan juga modal saham spesifik. Jika tingkat ROA tinggi, maka perusahaan dapat mengelola asset dengan baik dan menghasilkan laba yang tinggi begitu juga sebaliknya.Current ratio yang rendah biasanya dianggap menunjukkan, terjadinya masalah dalam likuidasi,sebaliknya current ratio yang terlalu tinggi juga kurang bagus, karena menunjukkan banyaknya dana menganggur yang pada akhirnya dapat mengurangi laba perusahaan juga, sehingga dapat mengurangi return yang seharusnya didapat oleh para investor.Adapun rasio yang digunakan dalam penelitian ini adalah Economic Value Added (EVA), Debt to EquityRatio(DER). Return onAsset (ROA),sdan Current Ratio (CR).Permasalahan (research problem) penelitian ditunjukkan dari penurunan return saham yang mengakibatkan para investor tidak mendapatkan keuntungan yang mereka inginkan serta karena adanya ketidakpastian kinerja perusahaan dan turunnya produktivitas serta penurunan permintaan ekspor. Untuk itu, tujuan penelitian yaitu untuk menganalisis pengaruh Economic Value Added (EVA), Debt To Equity Ratio (DER), Return On Asset (ROA), Dan Current Ratio (CR) Terhadap Return Saham (Studi Pada Perusahaan Sektor Pertambangan yang Terdaftar di Bursa Efek Indonesia Periode 2013-2017)

\section{Metodologi}

\subsection{Populasi dan Sampel}

Populasi dalam penelitian ini adalah return saham sektor pertambangan yang terdaftar di Bursa Efek Indonesia tahun 2013-2017 dengan jumlah keseluruhan sampai saat ini adalah 41 perusahaan. Pada penelitian ini sampel yang digunakan sebanyak 6 (enam) perusahaan yang memenuhi kriteria. Kriteria yang dimaksud meliputi perusahaan yang bergerak di sektor pertambangan, perusahaan yang telah go public dan terdatar di Bursa Efek Indonesia, perusahaan yang mempublikasi laporan keuangan dan telah diaudit selama periode 2013 sampai dengan 2017, laporan keuangan dicatat dalam mata uang IDR, dan data yang dibutuhkan pada variabel pelitian tersedia lengkap selama tahun 2013 sampai dengan tahun 2017. Teknik pengambilan sampel dengan cara purposive sampling. Purposivesampling adalah teknik penentuan sampel denganpertimbangan tertentu. Berdasarkan pemilihan sampel dengan menggunakan purposive sampling, maka diperoleh 6 saham perusahaan sektor pertambangan yang telah memenuhi syarat dan layak digunakan 
sebagai sampel penelitian. Saham sektor pertambangan yang terdaftar di Bursa Efek Indonesia selama periode 2013-2017 yang menjadi sampel dalam penelitian ini dapat dilihat pada Tabel 1.

Tabel 1. Sampel Penelitian

\begin{tabular}{ccl}
\hline No & Kode Saham & \multicolumn{1}{c}{ Nama Emiten } \\
\hline 1 & ELSA & Elnusa Tbk \\
\hline 2 & SMMT & Golden Eagle Energy Tbk \\
\hline 3 & RUIS & Radiant Utama Interinsco Tbk \\
\hline 4 & TINS & Timah (Persero) Tbk \\
\hline 5 & MITI & Mitra Investindo Tbk \\
\hline 6 & ANTM & Aneka Tambang (Persero) Tbk \\
\hline & Sumber : Data sekunder yang diolah, 2017 IDX
\end{tabular}

\subsection{Jenis dan Sumber Data}

Jenis data yang digunakan dalam penelitian ini adalah kuantitatif. Data kuantitatif dalam penelitian ini meliputi return saham, EVA, DER, ROA, dan CR. Sumber data laporan keuangan diperoleh dari Bursa Efek Indonesia (BEI) melalui Indonesian Capital Market Directory(ICMD), annual report yang diperoleh dari website www.idx.co.id dan data harga saham diperoleh dari www.finance.yahoo.com. Data yang digunakan dalam penelitian ini adalah data sekunder. Data sekunder adalah data yang diperoleh dalam bentuk sudah jadi, sudah dikumpulkan dan diolah oleh pihak lain.

\subsection{Metode Analisis Data}

Dalam penelitian ini, penulis menggunakan analisis regresi data panel. Menurut Kuncoro (2007:25), data Pooling (Panel) merupakan kombinasi antara data runtut waktu dan silang tempat. Tujuan penggunaan data ini umumnya untuk memperbanyak observasi guna memenuhi keperluan jumlah observasi minimum.

\section{Hasil Penelitian dan Pembahasan \\ 3.1 Statistik Deskriptif}

Analisis deskriptif menampilkan karakteristik sampel berdasarkan data dalam penelitian ini yang bertujuan untuk memberikan gambaran atau deskripsi suatu data yang dilihat dari jumlah sampel $(\mathrm{N})$, nilai rata-rata (mean), standar deviasi, nilai maksimum, dan nilai minimum. Data yang diteliti merupakan data panel, yaitu gabungan antara data time series dan cross section. Data yang diolah mencakup periode tahunan dari tahun 2013-2017. Hasil analisis deskriptif berdasarkan pengolahan data dengan program Eviews 9.

\begin{tabular}{cccccc}
\multicolumn{5}{c}{ Tabel 2. Statisti Deskriptif } \\
\hline & RETURN & EVA & DER & ROA & CR \\
\hline Mean & -0.063863 & 8.9288132 & 1.04483 & 2.051947 & 135.9291 \\
Median & -0.144585 & $1.68 \mathrm{E}+08$ & 0.680000 & 2.250000 & 84.00000 \\
Maximum & 0.931243 & $1.56 \mathrm{E}+11$ & 3.240000 & 13.49000 & 297.0000 \\
Minimum & -0.735526 & $-2.03 \mathrm{E}+11$ & 0.060000 & -12.13000 & 21.37000 \\
Std. Dev. & 0.423318 & $5.00 \mathrm{E}+10$ & 0.945443 & 4.676593 & 92.04986 \\
Skewness & 0.880686 & -1.298698 & 0.908434 & -0.217253 & 0.639469 \\
Kurtosis & 3.341722 & 13.19040 & 2.575080 & 5.464798 & 1.797754 \\
& & & & & \\
Jarque-Bera & 4.024004 & 138.2384 & 4.351961 & 7.830031 & 3.851345 \\
Probability & 0.133721 & 0.000000 & 0.113497 & 0.019940 & 0.145778 \\
Sum & & & & & \\
Sum Sq. Dev. & -1.915900 & $2.68 \mathrm{E}+09$ & 32.53450 & 61.55840 & 4077.872 \\
Observations & 5.196735 & $7.24 \mathrm{E}+22$ & 25.92202 & 634.2452 & 245722.1 \\
\hline
\end{tabular}

\subsection{Pemilihan Teknik Estimasi Regresi Data Panel}

Pemilihan teknik dalam menentukan estimasiregresi data panel pada penelitian ini ditentukan dengan menggunakan 3 uji perbandingan, yaitu uji perbandingan antara metodeCommon Effect Model dengan Fixed Effect Model (Chow Test), FixedEffect Model dengan Random Effect Model (Hausman Test) dan uji perbandingan antara Common Effect dengan Random Effect Model (Lagrange Multiple Test) (Widarjono, 2009:231). 


\subsection{Hasil Uji Chow (Chow test)}

Uji Chow digunakan untuk mengetahui manakah yang lebih baik antara teknik regresi data panel metode Common Effect dengan Fixed EffectModel. Berikut dapat dilihat hasil dari Uji Chow(Chow Test) dalam Tabel 3.

Tabel 3 Uji Chow

\begin{tabular}{lccc}
\hline Redundant Fixed Effects Tests & & \\
Equation: FIXED & & \\
Test cross-section fixed effects & & & \\
Effects Test & & d.f. & Prob. \\
\hline Cross-section F & 0.611520 & $(5,20)$ & 0.6922 \\
Cross-section Chi-square & 4.267898 & 5 & 0.5115 \\
\hline
\end{tabular}

Berdasarkan hasil uji F statistik dapat dikatakan bahwa model mengikuti Common Effect Model karena probabilitas cross-section Chi Square F sebesar 0,5115>0,05.

\subsection{Hasil Uji LM}

Uji LM adalah uji statistik yang digunakan untuk memilih antara common effect model atau random effect model.

Tabel 4. Uji LM

\begin{tabular}{|c|c|c|c|}
\hline \multicolumn{4}{|c|}{ Lagrange Multiplier Tests for Random Effects } \\
\hline \multicolumn{4}{|c|}{ Null hypotheses: No effects } \\
\hline \multicolumn{4}{|c|}{ Alternative hypotheses: Two-sided (Breusch-Pagan) and one-sided } \\
\hline \multicolumn{4}{|c|}{ (all others) alternatives } \\
\hline \multirow{4}{*}{ Breusch-Pagan } & \multicolumn{3}{|c|}{ Test Hypothesis } \\
\hline & \multicolumn{2}{|c|}{ Cross-section Time } & Both \\
\hline & 0.529837 & 0.145138 & 0.674975 \\
\hline & $(0.4667)$ & $(0.7032)$ & $(0.4113)$ \\
\hline Honda & -0.727899 & -0.380970 & -0.784089 \\
\hline King-Wu & -0.727899 & -0.380970 & -0.769224 \\
\hline Standardized Honda & -0.253318 & -0.102533 & -3.497233 \\
\hline Standardized King-Wu & -0.253318 & -0.102533 & -3.452498 \\
\hline Gourierioux, et al.* & -- & -- & $\begin{array}{l}0.000000 \\
(>=0.10)\end{array}$ \\
\hline
\end{tabular}

Sumber : Diolah menggunakan Eviews 9

Dapat dilihat dari Breusch-Pagan yaitu > dari 0,05. Sehingga menggunakan atau mengikuti Model Common Effect.

\subsection{Hasil Estimasi}

Berdasarkan hasil Chow Test dan LMTest, dapat disimpulkan bahwa metode analis datayang paling tepat dalam menganalisis data panel dalam penelitian ini adalah Common Effect Model yang dapat dilihat pada Tabel 5.

Tabel 5. Common Effect Model

Dependent Variable: RETURN

Method: Panel Least Squares

Date: 04/17/18 Time: 11:08

Sample: 20132017

Periods included: 5

Cross-sections included: 6

Total panel (balanced) observations: 30

\begin{tabular}{crrrr}
\hline \hline Variable & Coefficient & Std. Error & t-Statistic & Prob. \\
\hline \hline C & -0.183212 & 0.131371 & -1.394610 & 0.1754 \\
EVA & $-2.16 \mathrm{E}-13$ & $1.00 \mathrm{E}-12$ & -0.215597 & 0.8311 \\
DER & -0.133255 & 0.060510 & -2.202204 & 0.0371 \\
ROA & 0.046076 & 0.011459 & 4.021084 & 0.0005 \\
CR & 0.001246 & 0.000574 & 2.170284 & 0.0397 \\
\hline \hline R-squared & 0.680035 & Mean dependent var & -0.063863 \\
Adjusted R-squared & 0.628841 & S.D. dependent var & 0.423318 \\
S.E. of regression & 0.257897 & Akaike info criterion & 0.278500
\end{tabular}




\begin{tabular}{llll} 
Sum squared resid & 1.662773 & Schwarz criterion & 0.512033 \\
Log likelihood & 0.822503 & Hannan-Quinn criter. & 0.353209 \\
F-statistic & 13.28339 & Durbin-Watson stat & 2.085115 \\
Prob(F-statistic) & 0.000006 & & \\
\hline
\end{tabular}

Sumber : diolah menggunakan Eviews 9

\subsection{Pengujian Asumsi Klasik}

\section{a) Hasil Uji Normalitas}

Uji Normalitas bertujuan untuk menguji apakah dalam model regresi, variabel pengganggu atau residual mempunyai distribusi normal. Model regresi yang baik adalah memiliki distribusi data normal atau mendekati normal.

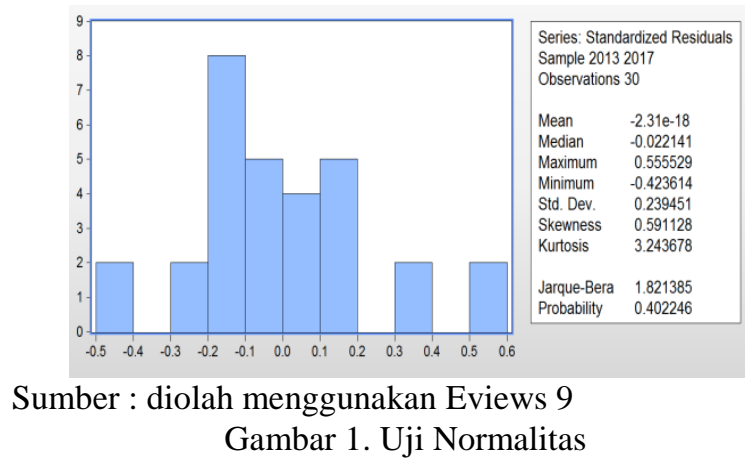

Dari gambar Grafik 1 di atas, dapat diketahui bahwa data yang ditunjukkan berupa probability 0,402246> 0,05 (taraf signifikansi 5\%) dapat disimpulkan, bahwa data dari variabel-variabel penelitian ini terdistribusi dengan normal dan memenuhi asumsi normalitas.

\section{b) Uji Multikolinearitas}

Menurut Ghozali dan Ratmono (2013:77), uji multikolinieritas bertujuan untuk menguji apakah dalam model regresi ditemukan adanya korelasi yang tinggi atau sempurna antar variabel independen.

Tabel 6. Hasil Uji Multikolinearitasdilihat dari Matrik Korelasi

\begin{tabular}{ccccc}
\hline & EVA & DER & ROA & CR \\
\hline EVA & 1.000000 & 0.188767 & -0.071611 & 0.145696 \\
\hline DER & 0.188767 & 1.000000 & -0.439603 & -0.351693 \\
\hline ROA & -0.071611 & -0.439603 & 1.000000 & 0.238258 \\
\hline CR & 0.145696 & -0.351693 & 0.238258 & 1.000000 \\
\hline
\end{tabular}

Sumber : diolah menggunakan Eviews 9

Tidak ada korelasi antar variabel independen yang tinggi di atas 0,90 , jadi dapat disimpulkan, bahwa tidak terdapat multikolinearitas antar variabel independen.

c) Uji Heteroskedastisitas

Uji Heteroskedastisitas bertujuan untuk menguji apakah dalam model regresi terjadi ketidaksamaan variance dari residual satu pengamatan ke pengamatan lain. Pada penelitian ini, untuk menguji ada atau tidak gejala heteroskedastisitas dalam model regresi digunakan Uji Glejser. 
Tabel 7. Hasil Uji Heteroskesdastisitas

Dependent Variable: ABS(RESID)

Method: Panel Least Squares

Date: 04/17/18 Time: 11:00

Sample: 20132017

Periods included: 5

Cross-sections included: 6

Total panel (balanced) observations: 30

\begin{tabular}{ccccc}
\hline \hline Variable & Coefficient & Std. Error & t-Statistic & Prob. \\
\hline \hline C & 0.141370 & 0.082982 & 1.703627 & 0.1009 \\
EVA & $7.90 \mathrm{E}-14$ & $6.34 \mathrm{E}-13$ & 0.124751 & 0.9017 \\
DER & 0.019639 & 0.038222 & 0.513819 & 0.6119 \\
ROA & 0.004459 & 0.007238 & 0.616037 & 0.5434 \\
CR & $6.89 \mathrm{E}-05$ & 0.000363 & 0.190000 & 0.8508 \\
\hline \hline
\end{tabular}

Sumber : Diolah menggunakan Eviews 9

\section{d) Uji Autokorelasi}

Uji Autokorelasi bertujuan menguji apakah dalam suatu model regresi linear ada korelasi antar kesalahan pengganggu (residual) pada periode t dengan kesalahan pada periode t-1 (sebelumnya). Jika terjadi korelasi, maka dinamakan ada masalah autokorelasi. Model regresi yang baik adalah regresi yang bebas dari autokorelasi.

\begin{tabular}{lrlr}
\hline \multicolumn{5}{c}{ Tabel 8 Hasil Uji Autokorelasi } \\
\hline R-squared & 0.680035 & Mean dependent var & -0.063863 \\
\hline Adjusted R-squared & 0.628841 & S.D. dependent var & 0.423318 \\
\hline S.E. of regression & 0.257897 & Akaike info criterion & 0.278500 \\
\hline Sum squared resid & 1.662773 & Schwarz criterion & 0.512033 \\
\hline Log likelihood & 0.822503 & Hannan-Quinn criter. & 0.353209 \\
\hline F-statistic & 13.28339 & Durbin-Watson stat & 2.085115 \\
\hline Prob(F-statistic) & 0.000006 & & \\
\hline mer : diolah menggunakan Eviews 9 & &
\end{tabular}

Uji ini dapat dikatakan tidak terjadi autokorelasi ketika nilai du $<\mathrm{dw}, 4-\mathrm{du}<\mathrm{d}$. Nilai du didapat dari Tabel Durbin Watson, dengan jumlah $\mathrm{n}=30$, dan $\mathrm{k}=4$ (jumlah variabel independen), maka didapat $\mathrm{dw}$ $=2,0851, \mathrm{du}=1,739,4-\mathrm{du}=2,261$. Sehingga, 1,739 $<2,0851<2,261$ tidak terdapat autokorelasi.

\subsection{Hasil Uji Kelayakan Data}

Ketepatan fungsi regresi sampel dalam menaksir nilai aktual dapat diukur dari goodness offit. Secara statistik dapat diukur dari nilai uji F,nilai uji t dan nilai koefisien determinasi.

a) Uji F

Uji Statistik F pada dasarnya menunjukkan apakah semua variabel independen yang dimasukkan dalam model mempunyai pengaruh secara bersama-sama atau simultan terhadap variabel dependen (Ghozali dan Ratmono, 2013:61).

Tabel 9 Hasil Uji F

\begin{tabular}{lrlr}
\hline \multicolumn{1}{c}{ R-squared } & 0.680035 & Mean dependent var & -0.063863 \\
\hline Adjusted R-squared & 0.628841 & S.D. dependent var & 0.423318 \\
\hline S.E. of regression & 0.257897 & Akaike info criterion & 0.278500 \\
\hline Sum squared resid & 1.662773 & Schwarz criterion & 0.512033 \\
\hline Log likelihood & 0.822503 & Hannan-Quinn criter. & 0.353209 \\
\hline F-statistic & 13.28339 & Durbin-Watson stat & 2.085115 \\
\hline Prob(F-statistic) & 0.000006 & & \\
\hline
\end{tabular}


Sumber : diolah menggunakan Eviews 9

Berdasarkan tabel di atas, menunjukan, bahwa $F_{\text {hitung }}$ sebesar 13,28339 dan nilai probabilitas F sebesar 0,000006. Apabila dibandingkan dengan taraf signifikansi 5\% $(\alpha=0,05)$ menunjukan hasil yang signifikan, karena nilai $F_{\text {hitung }} 5,652406$ lebih besar dari $F_{\text {tabel }} 2,74$ atau nilai probabilitas F $(0,000006)$ lebih kecil dari taraf signifikasi 5\% $(\alpha=0,05)$.

b) Uji t

Pengujian ini dimaksudkan untuk mengetahui secara individual apakah masing-masing variabel independen mempunyai pengaruh terhadap variabel dependen.

Tabel 10 Hasil Uji T

\begin{tabular}{ccccc}
\hline Variable & Coefficient & Std. Error & t-Statistic & Prob. \\
\hline C & -0.183212 & 0.131371 & -1.394610 & 0.1754 \\
\hline EVA & $-2.16 \mathrm{E}-13$ & $1.00 \mathrm{E}-12$ & -0.215597 & 0.8311 \\
\hline DER & -0.133255 & 0.060510 & -2.202204 & 0.0371 \\
\hline ROA & 0.046076 & 0.011459 & 4.021084 & 0.0005 \\
\hline CR & 0.001246 & 0.000574 & 2.170284 & 0.0397 \\
\hline
\end{tabular}

Sumber : diolah menggunakan Eviews 9

Pengujian hipotesis $1\left(\mathrm{H}_{1}\right)$ dilakukan dengan uji t. Berdasarkan Tabel 4.12 dihasilkan $\mathrm{t}_{\text {hitung }} \mathrm{EVA}=$ $0,215597>\mathrm{t}_{\text {tabel }}=-2,05553$ atau signifikansi $=0,8311>0,05$, maka yang berarti tidak terdapat pengaruh signifikan antara EVA secara parsial terhadap return saham.. Dengan demikian, hipotesis $1\left(\mathrm{H}_{1}\right)$ yang menyatakan, bahwa" EVA berpengaruh signifikan terhadap return saham"dinyatakan ditolak.

Pengujian hipotesis $2\left(\mathrm{H}_{2}\right)$ dilakukan dengan uji t. Berdasarkan Tabel 4.12 dihasilkan $\mathrm{t}_{\text {hitung }}$ DER $2,202204<\mathrm{t}_{\text {tabel }}=-2,05553$ atau signifikansi $0,0371<0,05$ maka yang berarti terdapat pengaruh signifikan antara DER secara parsial terhadap return saham. Dengan demikian, hipotesis $2\left(\mathrm{H}_{2}\right)$ yang menyatakan, bahwa" DER berpengaruh signifikan terhadap return saham "dinyatakan diterima.

Pengujian hipotesis $3\left(\mathrm{H}_{3}\right)$ dilakukan dengan uji t. berdasarkan Tabel 4.12 dihasilkan thitung R0A 4,021084> 2,0553 atau signifikansi 0,0005<0,05 maka yang berarti terdapat pengaruh signifikan antara ROAsecara parsial terhadap return saham. Dengan demikian, hipotesis $3\left(\mathrm{H}_{3}\right)$ yang menyatakan, bahwa“ ROA berpengaruh signifikanterhadap nilai saham"dinyatakan diterima.

Pengujian hipotesis $4\left(\mathrm{H}_{4}\right)$ dilakukan dengan uji t,berdasarkan Tabel 4.12 dihasilkan $t_{\text {hitung }}$ $\mathrm{CR}=2,170284>2,0553$ atau signifikansi $0,0397<0,05$ makayang berartiter dapat pengaruh ignifikan antaraCR secara parsial terhadap return saham. Dengan demikian, hipotesis $4\left(\mathrm{H}_{4}\right)$ yang menyatakan, bahwa" CR berpengaruh signifikan terhadap return saham"dinyatakan diterima.

\section{c) Koefisien Determinasi $\left(\mathbf{R}^{2}\right)$}

Pengujian pada koefisien determinasi digunakan untuk mengukur seberapa jauh kemampuan model dalam menerangkan variasi variabel dependen.

Tabel 11 Hasil Koefisien Determinasi

\begin{tabular}{cccc}
\hline R-squared & 0.680035 & Mean dependent var & -0.063863 \\
\hline Adjusted R-squared & 0.628841 & S.D. dependent var & 0.423318 \\
\hline S.E. of regression & 0.257897 & Akaike info criterion & 0.278500 \\
\hline Sum squared resid & 1.662773 & Schwarz criterion & 0.512033 \\
\hline Log likelihood & 0.822503 & Hannan-Quinn criter. & 0.353209 \\
\hline F-statistic & 13.28339 & Durbin-Watson stat & 2.085115 \\
\hline Prob(F-statistic) & 0.000006 & & \\
\hline
\end{tabular}

Sumber : diolah menggunakan Eviews 9

Hasil pengujian koefisien determinasi dapat dilihat dari nilai Adjusted $R$-Squared. Berdasarkan hasil estimasi yang diperoleh pada Tabel 4.13 menunjukan bahwa nilai koefisien determinasi $\left(\mathrm{R}^{2}\right)$ sebesar 0,628841 atau $62,8841 \%$.. ini artinya bahwa sebesar 62,88\% return saham banyak dipengaruhi oleh variabel independen, sedangkan sisanya sebesar $37,22 \%$ dipengaruhi oleh variabel independen lainnya. 


\subsection{Pembahasan}

\subsubsection{Pengaruh Economic Value Added (EVA) terhadap Return Saham}

Hipotesis pertama $\left(\mathrm{H}_{1}\right)$ dalam penelitian ini berbunyi "Economic Value Added berpengaruh signifikan terhadap return saham". Berdasarkan hasil pengujian yang telah dilakukan pada Tabel 4.12, hasil statistik uji t pada variabel Economic Value Added (EVA)diperoleh nilai thitung EVA sebesar -0,215597 lebih kecil jika dibandingkan $\mathrm{t}_{\text {tabel }}$ sebear - 2,05553. Berdasarkan hasil perbandingan tersebut, maka dapat disimpulkan bahwa hipotesis pertama $\left(\mathrm{H}_{1}\right)$ yang menyatakan "Economic Value Added berpengaruh signifikan terhadap return saham" ditolak.

Issabella (2013) mengatakan bahwa Economic Value Added (EVA) adalah metode manajemen keuangan untuk mengukur laba ekonomi dalam suatu perusahaan yang menyatakan, bahwa kesejahteraan hanya dapat tercipta manakala perusahaan mampun memenuhi semua biaya operasi dan biaya modal, suatu perusahaan dapat meningkatkan kekayaan pemegang sahamnya bila tingkat yang dihasilkan lebih besar daripada biaya modalnya. Laba ekonomi merupakan perbedaan antara total pendapatan moneter dan biaya total. Biaya-biaya total mencakup biaya eksplisit (misalnya biaya bahan baku, biaya gaji karyawan) dan implicit (misalnya gaji yang didapatkan oleh seorang ahli jika ia bekerja di perusahaan lain, gedung yang dimiliki secara pribadi oleh konsumen). Laba ekonomi diperoleh dari total pendapatan dikurangi total biaya peluang (opportunity cost). Laba ekonomi diperoleh dalam waktu yang lama/jangka panjang.

Jika EVA nya semakin tinggi, maka harga saham akan semakin tinggi. Hal ini dapat terjadi dikarenakan perusahaan tersebut telah berhasil menciptakan kekayaan bagi pemegang saham, sehingga berdampak terhadap kenaikkan return saham. Begitu pula sebaliknya, jika semakin rendah nilai EVA maka nilai return yang akan diperoleh investor akan berkurang. (Diana, 2010).

Pada penelitian ini, EVA tidak berpengaruh terhadap return saham. Pada penelitian sebelumnya, Issabella (2013) menyatakan, EVA berpengaruh signifikan terhadap return saham, yang sependapat, dengan Rizkita (2013) bahwa varabel EVA mempunyai pengaruh yang signifikan terhadap return saham. Berbeda dengan penelitian Janitra dan Kesuma (2015) yang menyatakan, bahwa EVA tidak berpengaruh signifikan terhadap return saham, yang ini sependapat dengan penelitian Mirbaksh dan Musarani (2015).

\subsubsection{Pengaruh Debt to Equity Ratio terhadap Return Saham}

Hipotesis kedua $\left(\mathrm{H}_{2}\right)$ dalam penelitian ini berbunyi "Debt to Equity Ratio (DER) berpengaruh signifikan terhadap return saham". Berdasarkan hasil pengujian yang telah dilakukan pada Tabel 4.12, hasil statistik uji t pada variabel Debt to Equity Ratio (DER)diperoleh nilai $t_{\text {hitung }}$ DER sebesar -2,202204 lebih besar jika dibandingkan $t_{\text {tabel }}$ sebear - 2,05553. Berdasarkan hasil perbandingan tersebut, maka dapat disimpulkan bahwa hipotesis pertama $\left(\mathrm{H}_{2}\right)$ yang menyatakan "Debt to Equity Ratio berpengaruh signifikan terhadap return saham" diterima.

Debt to Equity Ratio (DER) merupakan indikator struktur modal dan risiko financial, yang merupakan perbandingan antara utang dan modal sendiri. Semakin bertambah besanya DER suatu perusahaan, maka risiko distribusi laba usaha perusahaan akan semakin besar terserap untuk melunasi kewajiban perusahaan (Putri dan Sampurna, 2012).

Dalam penelitian ini menghasilkan, bahwa DER memiliki pengaruh negatif dan tidak signifikan terhadap return sahamnya sehingga hipotesis yang menyatakan bahwa DER berpengaruh negatif dan signifikan terhadap return saham pada perusahaan food and baverage di BEI ditolak. Hal ini dapat berarti, bahwa ada cara pandang yang berbeda mengenai nilai DER. Sebagian investor berpikir, bahwa semakin tinggi DER mencerminkan tingginya tingkat utang perusahaan sehingga akan meningkatkan risiko yang diterima investor sebagai akibat dari beban utang yang ditanggung perusahaan. Mencermati keadaan tersebut, akan terdapat kecenderungan investor tidak menanamkan modalnya di perusahaan tersebut, yang selanjutnya akan terjadi penurunan harga saham dan pada akhirnya akan berpengaruh terhadap turunnya return saham.

Disisi lain, terdapat investor yang berpandangan bahwa utang sangat dibutuhkan untuk menambah modal operaional perusahaan dan jika penggunaannya dioptimalkan oleh perusahaan, seperti melakukan pengelolaan aset, maka perusahaan memiliki kesempatan untuk meningkatkan penjualan. Terjadinya peningkatan penjualan berakibat perolehan laba perusahaan juga tinggi, sehingga informasi tersebut ditanggapi oleh investor secara positif, yang berakibat permintaan terhadap saham perusahaan juga akan meningkat. Hasil dari penelitian ini diperkuat oleh Hanani (2011), Malintan (2012) dan Daljono (2013) yang menyatakan bahwa DER berpengaruh negatif dan tidak signifikan terhadap return saham.

Siburian dan Daulay (2013), menyatakan Debt to Equity Ratio (DER) berpengaruh signifikan terhadap return saham, sependapat dengan hasil Thrisye dan Simu (2013), yang menyatakan, bahwa Debt to Equity Ratio (DER) mempunyai pengaruh yang signifikan terhadap return saham, sependapat pula dengan 
penelitian Hasibuan (2014) dan Putri dan Sampurno (2012). Sedangkan menurut Gunadi dan Kesuma (2015) bahwa Debt to Equity Ratio (DER) tidak memiliki hubungan yang signifikan terhadap return saham, sependapat dengan hasilnya Saputri (2016).

\subsubsection{Pengaruh Return on Asset terhadap Return Saham}

Hipotesis ketiga $\left(\mathrm{H}_{3}\right)$ dalam penelitian ini berbunyi "Return on Assetberpengaruh signifikan terhadap return saham". Berdasarkan hasil pengujian yang telah dilakukan pada Tabel 4.12, hasil statistik uji t pada variabel Return on Asset (ROA)diperoleh nilai $t_{\text {hitung }}$ ROA sebesar 4,021084 lebih besar jika dibandingkan $\mathrm{t}_{\text {tabel }}$ sebear 2,05553. Berdasarkan hasil perbandingan tersebut, maka dapat disimpulkan bahwa hipotesis pertama $\left(\mathrm{H}_{3}\right)$ yang menyatakan "Return on Asset berpengaruh signifikan terhadap return saham" diterima.

Pada hasil penelitian ini menunjukkan, bahwa ROA memiliki pengaruh positif signifikan terhadap return saham, sehingga hipotesis yang menyatakan ROA berpengaruh positif signifikan terhadap return saham pada perusahaan food and baverage di BEI diterima. Dengan semakin tingginya ROA berarti kinerja perusahaan semakin baik dan para pemegang saham akan memperoleh peningkatan keuntungan dari dividen yang diterima atau return saham, demikian pula sebaliknya (Kasmir, 2012). Hasil penelelitian ini memberikan dukungan terhadap hubungan antara keduannya, yakni jika nilai ROA semakin tinggi, maka perusahaan dianggap mampu memanfaatkan asetnya secara optimal guna mendapatkan laba bersih setelah pajak. Laba setelah pajak yang membaik, akan memberikan kepercayaan kepada investor karena dapat meningkatkan profitabilitas atau return yang dinikmati oleh para pemegang saham. Return saham yang meningkat, akan memberikan tanda baik bagi para calon investor yang akan menanamkan dananya ke perusahaan tersebut. Semakin banyak investor yang menanamkan dananya ke perusahaan yang bersangkutan, berarti dana yang masuk semakin bertambah, sehingga perusahaan dapat menambah asetnya untuk meningkatkan produktivitasnya. Penigkatan produktivitas akan mendorong bagi perusahaan untuk menghasilkan laba yang semakin tinggi, begitu seterusnya, menjadikan kepercayaan perusahaan meningkat.

Hasil penelitian ini menyatakan, bahwa Return On Asset (ROA) berpengaruh posisif terhadap return saham. Hasil ini didukung oleh Ariyanti dan Suwitho (2016) yang menyatakan, bahwa ROA berpengaruh terhadap return saham, sependapat dengan Siburian dan Dulay (2013), bahwa variabel ROA mempunyai pengaruh yang signifikan terhadap return saham. Pendapat di atas juga didukung oleh Puspitadewi dan Rahyuda (2016) serta Gunadi dan Kesuma (2015). Penelitian dari Kurnia dan Isynuwardhana (2015) bahwa ROA tidak berpengaruh signifikan terhadap return saham, sependapat dari hasil penelitian Savitri dan Haryanto (2011)

\subsubsection{Pengaruh Current Ratio terhadap Return Saham}

Hipotesis keempat $\left(\mathrm{H}_{4}\right)$ dalam penelitian ini berbunyi "Current Ratio berpengaruh signifikan terhadap return saham". Berdasarkan hasil pengujian yang telah dilakukan pada Tabel 4.12, hasil statistik uji t pada variabel Current Ratio (CR)diperoleh nilai $t_{\text {hitung }}$ CR sebesar 2,170284 lebih besar jika dibandingkan $t_{\text {tabel }}$ sebear 2,05553. Berdasarkan hasil perbandingan tersebut, maka dapat disimpulkan bahwa hipotesis pertama $\left(\mathrm{H}_{4}\right)$ yang menyatakan "Return on Asset berpengaruh signifikan terhadap return saham" diterima.

Current Ratio (CR) yang rendah dianggap dapat menimbulkan terjadinya masalah likuiditas, sebaliknya current ratio yang terlalu tinggi juga kurang bagus, karena menunjukkan banyaknya dana menganggur yang pada akhirnya dapat mengurangi laba perusahaan (Sawir, 2009). Namun, ketika perusahaan mampu memenuhi jumlah yang sesuai utang jangka pendek perusahaan, maka kelancaran bisnis dalam perusahaan akan berkembang dan berjalan lebih produktif, sehingga dapat mempengaruhi hasil keuntungan atau laba menjadi bertambah. Hal tersebut dapat mempengaruhi kenaikan return saham perusahaan pula. Sebaliknya, jika perusahaan tidak mampu memenuhi utang jangka pendek perusahaan, maka hal tersebut dapat memicu kerugian, dikarenakan adanya aset lancar yang menganggur. Banyaknya aset lancar yang menganggur ini menjadikan banyak aset lancar tidak digunakan, yang berarti modal kerja perusahaan untuk memperoleh keuntungan akan terganggu. Semakin terganggunya modal kerja, berarti akan sulit untuk mendapatkan keuntungan, sehingga akan menimbulkan gangguan untuk meningkatkan harga sahamnya.

Pada penelitian ini Current Ratio (CR) berpengaruh terhadap return saham. Hasil penelitian in sesuai dengan hasil Kandarini (2015) yang menyatakan, bahwa Current Ratio berpengaruh signifikan terhadap return saham, sependapat pula dengan Thamrin (2012). Sedangkan, menurut Nugroho dan Daljono (2013) menyatakan Current Ratio tidak berpengaruh signifikan terhadap return saham sependapat dengan Gejali dan Satrio (2013). 


\section{Kesimpulan.}

Tujuan dari penelitian ini adalah untuk menguji pengaruh signifikansi Economic Value Added (EVA), Debt to Equity Ratio (DER), Return on Asset (ROA)dan Current Ratio (CR terhadap return saham perusahaan sektor pertambangan yang terdaftar di Bursa Efek Indonesia periode tahun 2013-2017. Jumlah sampel yang digunakan dalam penelitian ini berjumlah 6 (enam) perusahaan yang diteliti selama 5 (lima) tahun yakni tahun 2013 hingga 2017 dan menghasilkan total sampel 30.

Penelitiaan ini menunjukan hasil pengujian sebagai berikut:

1. Model estimasi data yang sesuai dalam penelitian ini adalah Common Effect Model. Dengan persamaan sebagai berikut:

RETURN $=-0,183212-2,16 \mathrm{E}^{*} E V A_{i t}-0,133255^{*} D E R_{i t}+0,046076^{*} R O A_{i t}+0,001246 * C R_{i t}+\mathrm{e}_{i t}$

2. Berdasarkan hasil pengujian hipotesis $1\left(\mathrm{H}_{1}\right)$ menunjukan, bahwa Economic Value Added (EVA) berpengaruh namun tidak signifikan terhadap return saham perusahaan sector pertambangan yang terdaftar di Bursa Efek Indonesia periodetahun 2013-2017.

3. Berdasarkan hasil pengujian hipotesis $2\left(\mathrm{H}_{2}\right)$ menunjukan, bahwa Debt to Equity Ratio (DER) berpengaruh secara signifikan terhadap return saham perusahaan sector pertambangan yang terdaftar di Bursa Efek Indonesia periode tahun 2013-2017.

4. Berdasarkan hasil pengujian hipotesis $3\left(\mathrm{H}_{3}\right)$ menunjukan, bahwa Return On Asset (ROA) berpengaruh secara signifikan terhadap return saham perusahaan sector pertambangan yang terdaftar di Bursa Efek Indonesia periode tahun 2013-2017.

5. Berdasarkan hasil pengujian hipotesis $4\left(\mathrm{H}_{4}\right)$ menunjukan, bahwa Current Ratio (CR) berpengaruh secara signifikan terhadap return saham perusahaan sector pertambangan yang terdaftar di Bursa Efek Indonesia periodetahun 2013-2017.

\section{Saran}

Dengan melihat kesimpulan yang ada pada penelitian ini, diharapkan penelitian mendatang dapat memperhatikan hal-hal berikut ini.

1. Besarnya return saham dapat dipengaruhi oleh faktor lain atau variable lain sehingga diharapkan untuk penelitian dimasa mendatang peneliti dapat menggunakan variable lainnya yang terkait dengan return saham, seperti inflasi, SBI (Nasir dan Mirza, 2010).

2. Penelitian selanjutnya juga dapat mengganti obyek sampel penelitian, misalnya sector manufaktur (Ginting dan Edward, 2013), dimana sektor manufaktur memiliki jumlah emiten lebih banyak dibandingkan emiten di sector pertambangan.

\section{Daftar Pustaka}

Agnes, Sawir (2009). Analisa Kinerja Keuangan dan Perencanaan Keuangan. Perusahaan, Jakara : PT Gramedia Pustaka Utama

Ariyanti, Ajeng dan Suwitho (2016). Pengaruh CR, TATO, NPM, dan ROA terhadap Return Saham. Jurnal Ilmu dan Riset Manajemen; Vol 5 No 4; April 2016; ISSN : 2461 - 0593. STIE.

Bank Indonesia.( 2017). "Dokumen Perekonomian Indonesia”Diakses pada 27 Desember 2017 pukul 8 p.m. http://www.bi.go.id/web/id/perekonomianindonesia.

Bisnis, Berita.(2016). Perkembangan Ekonomi Makro Indosia. 28 Desember 2017. Diakses pukul 7 p.m. www.bisnis.com

Brigham, E.F dan J.F, Houston (2001). Manajemen Keuangan. Terjemahan Suharto, D dan H, Wibowo. Edisi Kedelapan. Jakarta: Erlangga.

Budiasih, Yanti(2012). Statistika Deskriptif untuk Ekonomi \& Bisnis. Tangerang:Jelajah Nusa.

Diana, Y.M. (2010). Analisis EVA dan MVA sebagai Metode Alternatif Penilaian Kinerja Keuangan dan Pengaruhnya terhadap Pengembalian Saham (Studi pada Perusahaan yang Tergabung dalam Indeks LQ 45 di Bursa Efek Indonesia tahun 2005-2008). Skripsi. Surakarta: Universitas Sebelas Maret.

Gejali, Andrianto dan Budhi Satrio. 2013.Pengaruh Current Ratio, Return On Equity dan Earning Per Share Terhadap Return Saham. Jurnal Ilmu \& Riset Manajemen Vol. 2 No. 6. STIESIA Surabaya

Ghozali, Imam danDwiRatmono. 2013. AnalisisMultivariatdanEkonometrika: Teori, Konsep, danAplikasidenganEviews. Semarang: UniversitasDiponegoro Semarang

Gilang, Gunadi dan I Ketut Kesuma. 2015. Pengaruh ROA, DER, EPS Terhadap Return Saham Perusahaan Food And Beverage BEI. Vol. 4, No. 6, 2015: 1636-1647; ISSN: 2302-8912. UDAYANA. 
Hanafi, Mamduh M dan Halim Abdul. 2005. Analisis Laporan Keuangan. Edisi. Kedua. Yogyakarta. UPPAMP YKPN

Harmono. 2015. Manajemen Keuangan Berbasis Balanced Scorecard: Pendekatan

Teori, Kasus dan Riset Bisnis. Edisi Pertama, Cetakan Keempat. Jakarta: PT Bumi Aksara.

Hartono, Jogiyanto. 2009. TeoriPortofoliodanAnalisisInvestasi. Yogyakarta: BPFE

Husnan, SuaddanEnnyPudjiastuti. 2012. Dasar-dasarManajemenKeuangan. Yogyakarta: UPP STIM YKPN IDX ."PT Bursa Efek Indonesia".27 Desember 2017.DiaksesPukul 7 p.m. https://www.idx.co.id.

Ika, Ardiani. 2008. Economic Value Edded (EVA): Suatu Alternatif Pengukuran Kinerja Perusahaan. Jurnal Solusi. Volume 7, Nomor 4, Universitas Semarang.

Indopremier, Financial.“Indopremier”.Diaksespada $26 \quad$ Desember 2017 pukul 8 p.m. https://www.indopremier.com.

Issabella, Mellissa. 2013. Pengaruh Economic Value Edded (EVA), Risiko Sistematis, dan Prediksi Kebangkrutan dengan Model Altman Z-Score terhadap Return Saham (Perusahaan Lembaga Keuangan yang Terdaftar di BEI tahun 2007-2011). Jurnal Akuntansi. Volume 1, Nomor 2, Universitas Negeri Padang.

Kadarini, Tri. 2015.Analisis Pengaruh Current Ratio, Debt To Equity Ratio, Quick Asset To Inventory Ratio dan Return On Asset Terhadap Return Saham. Universitas Jambi.

Kasmir. 2012. Analisis Laporan Keuangan. Jakarta : PT Raja Grafindo Persada.

Keown, A.J et al. 2004. Manajemen Keuangan: Prinsip-prinsip dan Aplikasi. Edisi Kesembilan. Terjemahan Haryandini. Jakarta: PT INDEKS Kelompok GRAMEDIA.

Kuncoro, Mudrajad. 2007. MetodeKuantitatif: TeoridanAplikasiUntukBisnisdanEkonomi. Yogyakarta: STIM YKPN

Margaretha, Farah. 2011. Manajemen Keuangan untuk Manajer Nonkeuangan. Jakarta: Erlangga.

Mirbakhsh and Musarani (2015).Application of economic value added in stock return evaluation of accepted oil productions companies in thehran stock exchange. The Caspian sea journal; ISSN : 1578-7899; Vol 9; Issue I.

Murhadi, Werner R.2015. Analisis Laporan Keuangan Proyeksi dan Valuasi Saham. Jakarta

Nugroho, Bramantyo dan Daljono. . 2013. Pengaruh Kinerja Keuangan Terhadap Return Saham (Studi Empiris Perusahaan Automotive and Component yang Listing di Bursa Efek Indonesia Periode 20052011). Volume 2, Nomor 1, Tahun 2013. Universitas Diponegoro.

Prastowo, Dwi .2002. Analisis Laporan Keuangan Konsep dan Aplikasi. Yogyakarta : Penerbit AMP YKPN.

Puspitadewi, Indah dan Rahyuda. 2016. Pengaruh DER, ROA, PER dan EVA Terhadap Return Saham Pada Perusahaan Food And Beverage Di BEI. E-Jurnal Manajemen Unud, Vol. 5, No. 3, 2016: 1429-1456. UNUD.

Putri, Anggun A.B dan R. DjokoSampurno. 2012. AnalisisPengaruh ROA, EPS, NPM, DER dan PBV Terhadap Return Saham (Studikasuspadaindustri Real Estate and Property yang terdaftar di Bursa Efek Indonesia periode 2007-2009). Vol. 1, No. 1. Semarang.

Rizkita, Cattleya. 2013. Analisis Kinerja Keuangan serta Pengaruhnya terhadap Return Saham pada Perusahaan Pertanian di Bursa Efek Indonesia. Skripsi. Bogor: Institut Pertanian Bogor.

Salim, Joko. 2012. Jangan Coba-Coba Main Saham Sebelum Baca Buku Ini. Cetakan 1. Jakarta: Visimedia.

Saputri, Widya. 2016. Pengaruh Current Ratio, Debt To Equity Ratio, Return On Equity, dan Total Asset Turnover Terhadap Initial Return SaatMelakukan Initial Public Offering Pada Perusahaan YangTerdaftar Di Bursa Efek IndonesiaPeriode 2008-2012. Skripsi. Universitas Negeri Yogyakarta.

Siburian, FriskaEviannadanMurniDaulay. 2013. AnalisisPengaruh Debt to Equity Ratio (DER), Return on Assets (ROA) Terhadap Return SahamPada Perusahaan Perbankan yang Terdaftar di Bursa Efek Indonesia. JurnalEkonomidanKeuangan Vol. 1 No.6

Sudana, I Made. 2015. ManajemenKeuangan Perusahaan TeoridanPraktik.Jakarta: Erlangga.

Sugiarto, dkk. 2003. Teknik Sampling. Jakarta: PT GramediaPustakaUtama

Tandelilin, Eduardus. 2001. Analisis Investasi dan Manajemen Portofolio. $\quad$ Yogyakarta : PT. BPFE.

Thamrin, Yulris. 2012. Analisis Current Ratio(CR) Dan Debt Equity Ratio (DER)Terhadap Return Saham Perusahaan Manufaktur yang Terdaftar di Bursa Efek Indonesia. Makassar: Universitas Hasanudin

Thrisye, RiscaYilianadan Nicodemus Simu. 2013. AnalisisPengaruhRasioKeuanganTerhadap Return Saham BUMN SektorPertambanganPeriode 2007-2010. JurnalllmiahAkuntansidanBisnis, Vol. 8, No. 2. Jakarta

Veda, Janitra dan Kesuma. 2015. Pengaruh EPS, ROI, dan EVA Terhadap Return Saham Perusahaan Otomotif Di BEI. E-Jurnal unud ; Vol 4 No 7. UNUD. 
Widarjono, Agus. 2009.EkonomikaPengantardanAplikasinya. Yogyakarta: EKONOSIA

Wuriyani, Diah. 2014. Analisis Pengaruh Price Earning Ratio (PER), Return OnEquity (ROE), Economic Value Added (EVA) dan Market Value Added (MVA) terhadap Return Saham LQ 45 yang Terdaftar di Bursa Efek Indonesia Periode 2009-2013. Tugas Akhir. Semarang: Politeknik Negeri Semarang.

Yahoo. "Yahoo! Finance". Diakses pada 26Desember 2017 pukul 7 p.m. https://finance.yahoo.com/ 